\title{
A Research on the Hatching Possibilities of Ovigerous Females of Crayfish (Astacus leptodactylus Esch. 1823) Obtained from Lakes in Bafra and Crayfish Larvae Farming in Sinop Region
}

\author{
Mustafa Palaz \\ The Ministry of Agriculture and Rural Affairs, \\ Provincial Administration of Agriculture of Canakkale, 17100 Canakkale, Turkey
}

\begin{abstract}
The research has been carried out at a carp farm in Cobanlar village which is $18 \mathrm{~km}$ far from Sinop using ovigerous females of 20 crayfish (Astacus leptodactylus Esch. 1823) from Bafra Fish Lakes. The larvae has been hatched at an average water temperature of $23.9 \pm 0.24^{\circ} \mathrm{C}$ in 19.05 .1994 . After hatching, the larvae have left the females after 10 days. Afterwards two ponds of earth with dimensions of $2 \times 3 \times 0.9$ m were used in order to observe the growth performance. About 250 individuals of larvae of crayfish were placed into each pond. Farm dung was used in one of earth ponds in order to enrich the natural food in the environment and the young individuals of the first group were fed on natural food while trout pellets were used in the second group which was maintaned in the other pond. According to the end of study, it has been recorded that growth in the pond where trout pellets were used proved. T-test controls showed that the difference is considerable $(\mathrm{p}<0.05)$.
\end{abstract}

Key words: Astacus leptodactylus, crayfish growing, decapoda, brachyura, larvae, Sinop

\section{INTRODUCTION}

Many types of crayfish are seen in lakes, rivers and dams in various parts of the world. However, there has been a decrease in crayfish production over the years due to damage caused by various pathogens especially in the early 19th century. Crayfish is enjoyed in many countries and therefore many studies are conducted towards development of techniques related to hatching of crayfish in artificial environment formation of new crayfish population by using the larvae produced in artificial environment and restoration of fresh water resources where crayfish population is low.

First production of crayfish larvae using an artificial method was realized by Soubeiran in 1959 in France. Today, sale of crayfish larvae for commercial purposes like in fishery industry have been performed in countries such as United States of America, Sweden and Russia (Abrahamsson, 1972; Avault, 1973, 1975; Lindqvist, 1977; Laurent, 1978; Arringnon, 1981).

Crayfish farming has developed in 2 ways. First of these is hatching of ovigereous females of crayfish and larvae production and the second one is growing of larvae until they are eligible to live in natural water resources (Cukerzis, 1973; Westman, 1973; Arringnon, 1981). Although restoration of water resources by mature crayfish is cheap and technically easy, there are some disadvantages such as they tend to have difficulty in adopting their natural habitat have certain food to have the possibility of spreading diseases. Therefore, youngsters of crayfish are more preferred than mature male and female crayfish as well as ovigerous females in the restoration of natural fresh water resources where crayfish population is low (Abrahamsson, 1973; Arringnon, 1981; Cukerzis, 1984). Newly hatched crayfish should be grown at least for a summer's period before they are released to natural water resources since the rates of death reach to $90 \%$ of the released crayfish under natural conditions in the first summer (Tcherkashina, 1977). High rates of death under natural conditions stress the need to larvae production under artificial conditions.

\section{MATERIALS AND METHODS}

Studies conducted in Turkey on crayfish have mostly concentrated on systematic, morphological and biological examination of crayfish (Geldiay and Kocatas, 1970; Erdemli, 1983), larva production (Erencin and Koksal, 1977; Koksal, 1982, 1983, 1984, 1985a, b) and larva farming (Koksal, 1983, 1984, 1985a, b; Koksal, 1988; Koksal et al., 1992).

Conducted research has examined hatching possibilities of ovigerous female crayfish obtained from lakes in Bafra and development phases of crayfish kept in two different ponds and under different feeding environments. Furthermore, importance of larvae farming in Sinop region for the restoration efforts of freshwater resources where crayfish population is low has been stressed since youngster crayfish have more advantages than ovigerous female crayfish such as easy adaptation to environment and protection from the hunters. 


\section{RESULTS AND DISCUSSION}

Findings related to larvae development: The larvae started to hatch in May in the water at a temperature of $23.9^{\circ} \mathrm{C}$. It was observed that the larvae left the ovigerous female crayfish after 10 days. During that time ovigerous female crayfish without larvae were taken to a different environment.

As it is shown in Table 1 and 2 , there was a slow down of the crayfish larvae length and weight developments in both environments starting from October and during the months of November and December.

The research concluded that every youngster crayfish (male and female) in the pond where natural conditions were established reached to $42.54 \pm 5.23 \mathrm{~mm}$ in total average length and $2.38 \pm 0.09 \mathrm{~g}$ in average weight. Furthermore, youngster crayfish in the pond where trout pellet was used reached to $47.6 \pm 0.23 \mathrm{~mm}$ total average length and $2.6 \pm 0.10 \mathrm{~g}$ average weight. Regression curves were drawn and correlation coefficients were calculated based on measurement results obtained in both pond environment and by establishing regression equations.

Regression equations and correlation values calculated according to gender are as follows: For the male crayfish larvae where farm dung was used:

$$
\mathrm{W}=0.00074 \mathrm{~L}^{2,1143}, \quad \mathrm{r}=0.93
$$

For the female crayfish larvae where farm dung was used:

$$
\mathrm{W}=0.00078 \mathrm{~L}^{2,0937}, \quad \mathrm{r}=0.93
$$

For the male crayfish larvae where trout pellet was used:

$$
\mathrm{W}=0.00134 \mathrm{~L}^{1,9638}, \quad \mathrm{r}=0.95
$$

A significant relationship was found between length and weight according to the calculated correlation coefficient. So it was observed that the more the length increased the weight increased as well.

Water used for larvae farming of crayfish should meet specifications of quality and temperature depending on the type of crayfish that is produced (Clark et al., 1975; Romaire et al., 1978; Arringnon, 1981). Cobanlar Village Carp Fish Production Facilities where we conducted the research was suitable for larvae of Astacus leptodaclylus type. It was observed in the study that the crayfish larvae which were kept in the pond where trout pellet was used grew better in relation to their length and weight than the larvae which were kept in the pond where farm dung was used. It was found significant in the conducted t-test controls $(\mathrm{p}<0.05)$. Although it was observed that male grew more than female individuals according to t-test controls the significance was found

\begin{tabular}{|c|c|c|c|c|c|c|}
\hline Months & Sex & Number & Parameters & $\mathrm{X} \pm \mathrm{S}_{\mathrm{x}}$ & Min.-Max. & Values (\%) \\
\hline First & Female + & 50 & Weight g) & $0.06 \pm 0.01$ & $0.05-0.090$ & 16.05 \\
\hline Measure & Male & & Total leght (mm) & $11.12 \pm 0.55$ & $10.00-13.00$ & 5.02 \\
\hline \multirow[t]{4}{*}{ June } & Male & 28 & Weight $(\mathrm{g})$ & $0.25+0.04$ & $0.19-0.320$ & 16.07 \\
\hline & & & Total leght $(\mathrm{mm})$ & $19.64+0.98$ & $17.00-21.00$ & 5.03 \\
\hline & Female & 22 & Weight (g) & $0.20+0.05$ & $0.14-0.310$ & 27.50 \\
\hline & & & Total leght (mm) & $19.00 \pm 1.37$ & $17.00-22.00$ & 7.25 \\
\hline \multirow[t]{4}{*}{ July } & Male & 17 & Weight $(\mathrm{g})$ & $0.61 \pm 0.09$ & $0.50-0.800$ & 18.98 \\
\hline & & & Total leght (mm) & $28.21+2.02$ & $25.00-33.00$ & 7.18 \\
\hline & Female & 33 & Weight $(\mathrm{g})$ & $0.59+0.11$ & $0.38-0.880$ & 18.98 \\
\hline & & & Total leght mrny & $27.94 \pm 2.16$ & $24.00-32.00$ & 7.74 \\
\hline \multirow[t]{4}{*}{ August } & Male & 25 & Weight (g) & $0.90+0.16$ & $0.69-1.420$ & 17.73 \\
\hline & & & Total leght (mm) & $32.92+2.73$ & $28.00-39.00$ & 8.31 \\
\hline & Female & 25 & Weight $(\mathrm{g})$ & $0.85+0.12$ & $0.66-1.070$ & 14.43 \\
\hline & & & Total leght (mm) & $32.04+2.52$ & $27.00-37.00$ & S.80 \\
\hline \multirow[t]{4}{*}{ September } & Male & 27 & Weight (g) & $1.39+0.26$ & $0.99-1.930$ & 19.15 \\
\hline & & & Total leght (mm) & $37.18+1.30$ & $34.03-39.00$ & 3.50 \\
\hline & Female & 23 & Weight $(\mathrm{g})$ & I $.35 \pm \ddot{0} .27$ & $0.96-1.910$ & 20.53 \\
\hline & & & Total leght (mm) & $36.30+1.25$ & $34.00-39.00$ & 3.46 \\
\hline \multirow[t]{4}{*}{ October } & Male & 26 & Weight (g) & $2.22 \pm 0.30$ & $1.7 \&-2.79$ & Î3.86 \\
\hline & & & Total leght (mm) & $42.15 \pm 2.97$ & $35.00-47.00$ & 7.05 \\
\hline & Female & 24 & Weight $(\mathrm{g})$ & $2.06 \pm 0.31$ & $1.40-2.700$ & 15.43 \\
\hline & & & Total leght (mm) & $41.41 \pm 2.14$ & $38.00-45.00$ & 5.17 \\
\hline \multirow[t]{4}{*}{ November } & Male & 30 & Weight $(\mathrm{g})$ & $2.44 \pm 0.47$ & $1.62-4.010$ & 19.52 \\
\hline & & & Total leght (mm) & $42.62 \pm 2.63$ & $37.00-51.03$ & 6.18 \\
\hline & Female & 20 & Weight $(\mathrm{g})$ & $2.22+0.44$ & $1.46-2.880$ & 19.89 \\
\hline & & & Total leght (mm) & $41.75+2.23$ & $36.00-47.00$ & 5.34 \\
\hline \multirow[t]{4}{*}{ December } & Male & 26 & Weight $(\mathrm{g})$ & $2.4 \mathrm{~S} \pm 0.47$ & $1.69-4.050$ & 18.90 \\
\hline & & & Total leght (mm) & $43.17 \pm 2.95$ & $37.00-52.00$ & 6.84 \\
\hline & Female & 22 & Weight $(\mathrm{g})$ & $2.27+0.44$ & $1.48-2.930$ & 19.30 \\
\hline & & & Total leght (mm) & $42.09+2.15$ & $36.00-47.00$ & 5.03 \\
\hline
\end{tabular}
insignificant $(\mathrm{p}>0.05)$.

Table 1: Findings related to development of crayfish larvae in the pond where farm dung was used to feed the larvae 


\begin{tabular}{|c|c|c|c|c|c|c|}
\hline Months & Gender & Number & Parameters & $\mathrm{X} \pm \mathrm{S}_{\mathrm{y}}$ & Min.-Max. & Values $(\%)$ \\
\hline First & Female + & 50 & Weight (g) & $0.06 \pm 0.010$ & $0.04-0.090$ & 18.74 \\
\hline Measure & Male & & Total leght (mm) & $11.22 \pm 0.460$ & $10.00-12.00$ & 4.14 \\
\hline \multirow[t]{4}{*}{ June } & Male & 28 & Weight (g) & $0.29 \pm 0.040$ & $0.18-0.380$ & 16.97 \\
\hline & & & Total Leght (mm) & $20.35 * 1.350$ & $18.00-22.00$ & 6.57 \\
\hline & Female & 22 & Weight (g) & $0.25 \pm 0.040$ & $0.18-0.320$ & 18.57 \\
\hline & & & Total leght $(\mathrm{mm})$ & $19.86 \pm 0.990$ & $18.00-21.00$ & 4.98 \\
\hline \multirow[t]{4}{*}{ July } & Male & 19 & Weight (g) & $0.93+0.160$ & $0.69-1.440$ & 18.14 \\
\hline & & & Total leght $(\mathrm{mm})$ & $32.57+2.710$ & $28.00-38.00$ & 8.33 \\
\hline & Female & 31 & Weight (g) & $0.89+0.220$ & $0.55-1.430$ & 24.85 \\
\hline & & & Total leght (mm) & $31.58+1.920$ & $27.00-35.00$ & 6.10 \\
\hline \multirow[t]{4}{*}{ August } & Male & 25 & Weight (g) & $1.30+0.230$ & $0.95-2.010$ & 17.91 \\
\hline & & & Total leght (mm) & $37.04+2.130$ & $33.00-43.00$ & 5.75 \\
\hline & Female & 25 & Weight (g) & $1.16 \pm 0.120$ & $0.91-1.480$ & 17.26 \\
\hline & & & Total leght (mm) & $36.12+1.610$ & $32.00-40.00$ & 4.47 \\
\hline \multirow[t]{4}{*}{ September } & Male & 26 & Weight (g) & $1.77+0.270$ & $1.34-2.350$ & 15.76 \\
\hline & & & Total leght (mm) & $40.88+2.840$ & $37.00-49.00$ & 5.99 \\
\hline & Female & 24 & Weight (g) & $1.56+0.310$ & $0.78-2.050$ & 20.12 \\
\hline & & & Total leght (mm) & $38.70+2.860$ & $29.00-44.00$ & 7.40 \\
\hline \multirow[t]{4}{*}{ October } & Male & 27 & Weight (g) & $2.87+0.320$ & $2.00-3.630$ & 11.39 \\
\hline & & & Total leght (mm) & $46.30 \pm 1.490$ & $41.00-43.00$ & 3.21 \\
\hline & Female & 23 & Weight (g) & $2.33 \pm 0.420$ & $1.77-3.670$ & 18.37 \\
\hline & & & Total leght (mm) & $44.75+2.060$ & $39.00-48.00$ & 4.62 \\
\hline \multirow[t]{4}{*}{ November } & Male & 29 & Weight (g) & $3.01+0.630$ & $1.95-4.400$ & 21.12 \\
\hline & & & Total leght (mm) & $47.46+3.290$ & $39.00-53.00$ & 6.93 \\
\hline & Female & 21 & Weight (g) & $2.61 \pm 0.390$ & $1.94-3.730$ & 15.00 \\
\hline & & & Total leght (mm) & $45.09+2.040$ & & 4.43 \\
\hline \multirow[t]{4}{*}{ December } & Male & 25 & Weight (g) & $3.04+0.590$ & $1.98-4.450$ & 18.42 \\
\hline & & & Total leght (mm) & $47.53 \pm 3.250$ & $40.00-53.00$ & 6.84 \\
\hline & Female & 24 & Weight (g) & $2.74+0.470$ & $1.95-3.910$ & 17.15 \\
\hline & & & Total leght $(\mathrm{mm})$ & $45.16 \pm 1.900$ & $40.00-49.00$ & 4.12 \\
\hline
\end{tabular}

Actually Koksal (1985b) and also stated that male crayfish grow more than female crayfish in their studies. Slow down of growth was observed by the decrease of water temperature in the study. During the months of November and December water temperature feeding of crayfish slowed down and when the water temperature decreased below $10^{\circ} \mathrm{C}$ the feeding of crayfish stopped and their growth slowed day by day. Muller also states that crayfish stop feeding when the water temperature is below $10^{\circ} \mathrm{C}$.

Moreover, a strong relation was found between weight and length by calculation of correlation coefficients. At the end of the study, the results related to pond environment where farm dung was used were found lower than the similar 6 months study of Tcherkashina (1977) in which Astacus lepiodactylus cubanicus larvae were used. However, the results were found better than the study of Pursiainen et al. (1983) in which Astacus astacus type were used in an environment where natural food + farm dung were used for 80 days in earth pond. Moreover, obtained findings stated that the study was better than the studies of Cukerzis et al. (1979) in which Astacus astacus type of crayfish was used in natural fresh water resources and study in which Astacus lepiodactylus was used in natural fresh water resources. Findings of the study regarding the larvae fed by trout pellet were found low compared to Kossman (1973) study in which Astacus leptodaclylus larvae were kept and fed by trout pellet, boiled potato and chironomids for 35 days and Koksal et al. (1992) study in which Aslacus leplodactylus larvae were kept and fed by trout pellet for 4 months in an earth soil.

However, the findings of the study were better than the studies of Meyers et al. (1970) in which Pasifastacus clarkii was kept and fed by specially prepared crustacean feed for 91 days; Cuellar and Ve Coll's (1978) study in which Actacus pallipes larvae was kept and fed by tubifex, daphnia and trout pellet for 2 months period; Koksal's (1982) study in which Astacus leplodactylus larvae were kept and fed by trout pellet and green algae for 90 days and Pursiainen et al. (1983) study in which Astacus astacus larvae were kept and fed by zooplanktons + frozen food $(1 / 3$ fish $+1 / 3$ vegetative food $+1 / 3$ shrimp shell) for 80 days. Similar duration or same duration were used for the comparison of the findings of the study in order to compare it with the other studies.

\section{CONCLUSION}

As a result, findings of the study put forward that Astacus leplodactylus type of crayfish farming can be performed under cultivation conditions in Sinop. Moreover, similar trial studies towards forming new crayfish areas in domestic water resources such as Bektasaga, Tasmanli, Cobanlar, Espiyeli, Katirli, Sarikum, Maruf, Edil, Cemalettin and Kelperenbektas lakes in Sinop can be conducted for ideal larvae farming. 
Crayfish populations which have an important place in the fishery products of the country but which were lost due to the damage caused by pathogenic factors should be leveled to its past numbers and controlled crayfish larvae production should be performed for the creation of new crayfish areas for the benefit of Turkish fishery production.

\section{REFERENCES}

Abrahamsson, S., 1972. Fecundity and grovth of some populations of Astacus astacus L. Sweden. Rep. Inst. Freshwater Res. Drottingholm, 52: 23-37.

Abrahamsson, S., 1973. Method for restoration of crayfish waters in Europe: The development of on industry for production of young of Pasifastacus leniusculus Dana, Freshwater Crayfish, 1: 203-210.

Arringnon, J., 1981. L'ecrevisse et Son Elevage. Gaunthier-Villars, Paris.

Avault, Jr. J.W., 1973. Crayfish Farming in the United States. In: Freshwater Crayfish, Abrahamsson, S. (Ed.). Studentliteratur Lund, Sweden, pp: 239-250.

Avault, Jr. J.W., 1975. Freshwater Crayfish Papers from the Second International Symposium of Freshvvater Crayfish. Vol. 2, Baion Rouge, Louisiana, USA., pp: 5 .

Clark, F.D., J.W. Awault, S.P. Meyers, 1975. Effects of feeding, fertilization and vegetation on production of red swamp crayfish (Procambarus clarkii). Freshwater Crayfish, 2: 125-138.

Cuellar, L. and M. ve Coll, 1978. First essay of controlled breeding of Astacus pallipes (1er). Freshwater Crayfish, 4: 273-276.

Cukerzis, J., 1973. Biologische grundlagen der methode der kunstlichen aufzucht der brut des Astacus astacus L. Freshwater Crayfish, 2: 188-201.

Cukerzis, J., 1984. La Biologie de L'ecrevisse (Astacus astacus L.). Editions Mintis, Vilnyus, 1970, INRA Puplications, Versailles, ISBN-10: 2853405583, pp: 313.

Cukerzis, J.J., S. Sheeshtok and A.L. Terentyev, 1979. Methods of accelerated artificial breeding of crayfish juveniles. Freshwater Crayfish, 4: 451-458.

Erdemli, U., 1983. A comperative research on the biological and morphological characteristics of crayfish (Astacus leptodactylus, Esch 1823) in beysehir, egirdir, aksehir, eber lakes and apa dam. J. Nature Sci., 7: 313-318.

Erencin, Z. and G. Koksal, 1977. On the crayfish Astacus leptodactylusi in anatolia. Freshwater Crayfish, 3: $187-192$.

Geldiay, R. and A. Kocatas, 1970. Disturibution of decapoda population in Turkey and their taxonomy. Ege University, Faculty of Science, Scientific Repords Series, 94, Biologie 63.
Koksal, G., 1982. Production of crayfish of aksehir lake (Astacus leptodaetylus salinus Nordmann1842) in sakaryabasi fish production and research station, examinations on the feding of juvenile. Faculty of Veterinary, University of Ankara.

Koksal, G., 1983. Turkish crayfish-a success. Infofish Marketmg Digest, b, 14-16.

Koksal, G., 1984. Crayfish (Aslacus Icploclaclylus salinus N'oidniann 1842) eggs and studies about their embrionic and post-embrionic development phases. E.U. J. Fishery Prod., 1: 38-55.

Koksal, G., 1985a. Studies on the reproduction performance crayfish under cultivation conditions (Aslacus leptodactylus salinus, Nordmann 1842). E.U. J. Fishery Prod., 2: 42-56.

Koksal, G., 1985b. Larvae production of crayfish (Astacus leptodactylus salinus Nordmann 1842) under cultivation conditions, E.U. J. Fishery Prod., 2: 61-76.

Koksal, G., 1988. Astacus leptodactylus in Europa. In: Freshvvater Crayfish, Biology, Management and Exploitation, Holdich, D.M. and R.S. Lowery (Eds.). Croom Holm, London.

Koksal, G., M. Olmez, S. Bekcan and A.S. Guler, 1992. Crayfish (Astacus leptodactylus Esch. 1823) for the restoration of natural water resources, larvae production, I.U. J. Fishery Prod., 1: 1-16.

Kossman, H., 1973. Haltungs-und vermehrungsversuche von susswasserkrebsen im haus. Freshwater Crayfish, 1: 222-231.

Laurent, P.J., 1978. Freshwater crayfish 4. papers from the fourth international symposium on freshwater crayfish. Thonon-les Bains France.

Lindqvist, O.V., 1977. Freshwater crayfish 3. papers from the third international symposium of freshwater crayfish. Kuopio, Finland.

Meyers, S.P., J.W. Avault, J.S. Rhee and D. Butler, 1970. Development of rations for economicaly important aquatic and marine invertebrates. Coastal Studies Bull., 5: 157-172.

Pursiainen, M., T. Jasvevpaa and K. Ivestman, 1983. A comparative study of the production of crayfish juveniles (Astacus astacus L.) in natural ponds and by feeding in plastic basins. Freslnvater Crayfish, 5: $392-402$.

Romaire, R.R., S. Forester and W. Aivault, 1978. Grouth and survival of stunted red svamp crayfish (Procambanis clarkii) in a feeding-stocking density experiment in pools. Freshwater Crayfish, 4: 331-336.

Tcherkashina, N.Y., 1977. Survival growth and feeding dinamics of juvenile crayfish (Astacus leptodactylus cubanicus) in ponds and river don. Freshvvater Crayfish, 3: 95-100.

Westman, K., 1973. Cultivation of the American Crayfish (Pasifastacus leniusculus) in Abrahamsson (Ed.). Freshvvater Crayfish, 1: 211-218. 